\title{
EVALUATION OF PERENNIAL FORAGE LEGUMES AND HERBS IN SIX MEDITERRANEAN ENVIRONMENTS
}

\author{
Daniel Real ${ }^{*}$, Guangdi D. Li², Steve Clark ${ }^{3}$, Tony O. Albertsen ${ }^{4}$, Richard C. Hayes ${ }^{2}$, Matt D. Denton ${ }^{5}$, \\ Mario F. D'Antuono ${ }^{4}$, and B.S. Dear ${ }^{2}$
}

\begin{abstract}
There is an absence of drought tolerant herbaceous perennial forage legume and herb options other than lucerne (Medicago sativa L.) for environments with Mediterranean-like climates common in extensive areas of Southern Australia, the Mediterranean basin, and Chile. Therefore, a collection of 174 forage perennial legume and herb entries from 103 species and 32 genera was evaluated for adaptation in a diverse range of Mediterranean climatic environments in Southern Australia. The seasonal rainfall distribution varied from moderately to highly winter dominant with long term average annual rainfall ranging from 318 to $655 \mathrm{~mm}$. The entries were rated for productivity and persistence over $3 \mathrm{yr}$. The 12 entries identified as the most promising for winter, summer, or all-year round production included Bituminaria bituminosa (L.) C.H. Stirt. var. albomarginata; Cichorium intybus L.; Cullen australasicum (Schltdl.) J.W. Grimes; Dorycnium hirsutum (L.) Ser.; Kennedia prostrata R. Br.; Lotononis bainesii Baker, Lotus pedunculatus Cav.; L. corniculatus L.; L. cytisoides L.; Medicago sativa subsp. sativa L.; Medicago sativa subsp. caerulea (Less. ex Ledeb.) Schmalh., and $M$. sativa subsp. falcata (L.) Arcang. These entries maintained production and persisted for the period of the evaluation, with the exception of $C$. intybus and L. corniculatus that declined in persistence over time. The potential role of these species in extensive grazing systems in Mediterranean climatic zones, their attributes and limitations, and current progress in developing them as useful forage plants was discussed.
\end{abstract}

Key words: Bituminaria, Lotus, herbage yield, legume persistence, Australian native germplasm.

$\mathrm{T}$ here is an absence of drought tolerant herbaceous perennial forage legume and herb options other than lucerne (Medicago sativa L.) for environments with Mediterranean-like climates common in extensive areas of southern Australia, the Mediterranean basin, and Chile (Dear et al., 2003; Li et al., 2008). In their extensive review of species adapted to Australian pastures, Gramshaw et al. (1989) listed six temperate perennial legumes widely sown in southern Australia; of these, only lucerne has sufficient drought tolerance to withstand the moisture stress and extended droughts typical of Mediterranean-like

${ }^{1}$ Future Farm Industries Cooperative Research Centre, The University of Western Australia, 35 Stirling Highway, Crawley, WA 6009 , Australia.

"Corresponding author (daniel.real@agric.wa.gov.au)

${ }^{2}$ E.H. Graham Centre for Agricultural Innovation (NSW Department of Primary Industry and Charles Sturt University), Wagga Wagga Agricultural Institute, PMB, Wagga Wagga, NSW 2650, Australia.

${ }^{3}$ Department of Primary Industries, Private Bag 105, Hamilton, VIC, 3300 , Australia.

${ }^{4}$ Department of Agriculture and Food, Western Australia, South Perth, WA 6151, Australia.

${ }^{5}$ Department of Primary Industries, RMB 1145 Chiltern Valley Road, Rutherglen, VIC 3685, Australia. Present address: School of Agriculture, Food and Wine, The University of Adelaide, PMB1 Glen Osmond SA 5064, Australia.

Received: 12 January 2011.

Accepted: 26 May 2011 climates. The greater use of lucerne is in part constrained by poor adaptation to acidic or waterlogged soils and lack of persistence under continuous grazing (Humphries and Auricht, 2001). The other perennial legumes identified by Gramshaw et al. (1989) were white clover (Trifolium repens L.), strawberry clover (T. fragiferum L.), red clover (T. pratense L.) and birdsfoot trefoil (L. corniculatus L.) and all are adapted to higher rainfall $(>700 \mathrm{~mm})$ regions or localised drainage areas (Gramshaw et al., 1989; Reed and Flinn, 1993). Current cultivars of these species lack the drought tolerance necessary to survive in regions that experience pronounced summer droughts (Lolicato, 1993).

While lucerne is clearly a highly drought tolerant temperate perennial legume, it is also highly competitive with annual forage species (Dear and Cocks, 1997), often leading to a monoculture which, when grazed at particular periods, can lead to animal health disorders such as bloat (FitzGerald et al., 1980) or red-gut (Gumbrell, 1997).

The case for increasing the diversity of legumes in pastures was made by Oram (1993) and Cocks (2001). The main drivers include better exploitation of diverse ecological niches, buffering against pests and diseases and achieving more sustainable soil management. Alternative perennial legume options have the potential to complement and expand the feed base for grazing livestock and provide fixed soil $\mathrm{N}$ and weed control options 
in cropping rotations. In addition, new species should assist in combating soil degradation attributable to deep drainage by using more out-of-season rainfall compared with predominantly winter growing annual pastures and cropping systems and be sufficiently persistent to incrementally dry the soil profile over successive years (Sandral et al., 2006; Dear and Ewing, 2008). The need for increased species diversity and the advantages this would convey are relevant not only to Australian pastures but to pastures in similar agroecological environments worldwide (Russi et al., 2003).

As the first step in increasing the diversity of perennial forage species Cocks (2001; 2003) and Dear et al. (2003) conducted reviews to identify a priority group of species potentially adapted to Mediterranean environments of southern Australia that warranted further evaluation. The Cooperative Research Centre for Plant-based Management of Dryland Salinity (Salinity CRC) subsequently commenced a field screening program using a multi-stage process, as described by Dear and Ewing (2008). The field studies conducted at 10 sites across southern Australia evaluated 45 species from 22 genera and identified a number of perennial legume and herbaceous species whose performance justified more detailed evaluation (Li et al., 2008; Reed et al., 2008). Based on these prior studies, accessions of the more promising species and an expanded range of previously untested species identified from a desktop review of species adapted to Mediterranean and temperate environments were sourced from collaborating partners/genetic resource centres or by collecting them in their natural environments, together with their associated root nodule bacteria (RNB) (Hughes et al., 2008).

The current study tested the production and persistence of a large group of promising herbaceous perennial species and accessions compared with lucerne at a diverse range of sites across southern Australia to identify new or unexploited species that may warrant further development for use in regions with Mediterranean-like environments.

\section{MATERIALS AND METHODS}

\section{Site description}

Six row nurseries were established across southern Australia at Wagga Wagga and Binalong in New South Wales (NSW), Katanning and Newdegate in Western Australia (WA), and Byawatha and Bealiba in Victoria. All nurseries were sown in 2005, except for Bealiba which was sown in 2006. All six experimental sites were located in non-saline, non-waterlogged areas. The two NSW sites were typical of the medium rainfall crop/pasture zones of the Riverina and Slopes regions respectively of southern NSW. Soils at both sites were acidic, with the Binalong soil containing Al and Mn levels likely to inhibit lucerne growth. The two WA sites were acidic but lucerne is able to perform well and farmers successfully grow it in these soils, most likely due to low Al levels $(<6 \%$ in the top $10 \mathrm{~cm}$ ) and negligible $\mathrm{Mn}$. The site in North East Victoria at Byawatha was typical of the high rainfall livestock and crop mixed farming zone. The central Victorian site, Bealiba, was on an acid granitic soil. The soil chemical characteristics at each site are presented in Table 1.

\section{Climatic data}

Four of the six sites have a strongly winter-dominant rainfall pattern (Table 2) with the other two sites (Binalong and Wagga Wagga) having a non-seasonal rainfall distribution although the growing season at these sites is also mostly confined to the cooler months due to very high evaporation rates over summer. The Binalong site had the highest long term average annual rainfall $(655 \mathrm{~mm})$ and the Newdegate site the lowest

Table 1. Soil chemical analysis at depths of $0-0.10 \mathrm{~m}$ and $0.10-0.20 \mathrm{~m}$ for each site.

\begin{tabular}{|c|c|c|c|c|c|c|c|c|c|c|c|c|}
\hline \multirow{2}{*}{$\begin{array}{l}\text { State } \\
\text { Site } \\
\text { Location } \\
\end{array}$} & \multicolumn{4}{|c|}{ New South Wales } & \multicolumn{4}{|c|}{ Western Australia } & \multicolumn{4}{|c|}{ Victoria } \\
\hline & \multicolumn{2}{|c|}{$\begin{array}{c}\text { Wagga Wagga } \\
\text { Wagga Wagga } \\
\text { Agricultural Institute }\end{array}$} & \multicolumn{2}{|c|}{$\begin{array}{l}\text { Binalong } \\
\text { Private } \\
\text { landholder }\end{array}$} & $\begin{array}{r}\text { Kat } \\
\text { Great } \\
\text { Agri } \\
\text { Researc }\end{array}$ & $\begin{array}{l}\text { nning } \\
\text { outhern } \\
\text { ultural } \\
\text { Institute }\end{array}$ & \multicolumn{2}{|c|}{ Newdegate } & \multicolumn{2}{|c|}{ Byawatha } & \multicolumn{2}{|c|}{ Bealiba } \\
\hline $\begin{array}{l}\text { Latitude, }{ }^{\circ} \mathrm{S} \\
\text { Longitude, }{ }^{\circ} \mathrm{E} \\
\text { Elevation, m.a.s.l. } \\
\text { Average rainfall, mm } \\
\text { Australian soil classification }\end{array}$ & Red $\mathrm{r}$ & $\begin{array}{l}\circ 05 \\
{ }^{\circ} 35 \\
20 \\
27 \\
\text { andosol }\end{array}$ & $\begin{array}{r}34 \\
14 \\
\text { Yellow }\end{array}$ & $\begin{array}{l}{ }^{\circ} 36^{\prime} \\
3^{\circ} 40^{\prime} \\
88 \\
55 \\
\text { Kandosol }\end{array}$ & Grey & $\begin{array}{l}3^{\circ} 42^{\prime} \\
7^{\circ} 37^{\prime} \\
309 \\
428 \\
\text { Sodosol }\end{array}$ & Yellow & $\begin{array}{l}{ }^{\circ} 06 \\
{ }^{\circ} 49 \\
30 \\
18 \\
\text { Chromosol }\end{array}$ & $\begin{array}{r}36 \\
14 \\
\text { Red D }\end{array}$ & $\begin{array}{l}10 \\
\circ 54 \\
50 \\
25 \\
\text { ermosol }\end{array}$ & $\begin{array}{r}36 \\
14 \\
\mathrm{Ku}\end{array}$ & $\begin{array}{l}49 \\
\circ 35 \\
60 \\
60 \\
69 \\
\text { osols }\end{array}$ \\
\hline Soil depth, m & $0-0.10$ & $0.10-0.20$ & $0-0.10$ & $0.10-0.20$ & $0-0.10$ & $0.10-0.20$ & $0-0.10$ & $0.10-0.20$ & $0-0.10$ & $0.10-0.20$ & $0-0.10$ & $0.10-0.20$ \\
\hline $\begin{array}{l}\mathrm{pH}\left(\mathrm{CaCl}_{2}\right) \\
\mathrm{EC}, \mu \mathrm{sm}^{-1}\end{array}$ & $\begin{array}{r}4.4 \\
6.8 \\
45\end{array}$ & $\begin{array}{r}4.6 \\
7.1 \\
18\end{array}$ & $\begin{array}{r}4.1 \\
4.3 \\
170\end{array}$ & $\begin{array}{r}4.0 \\
2.3 \\
80\end{array}$ & $\begin{array}{r}4.6 \\
4.0 \\
36\end{array}$ & $\begin{array}{r}4.4 \\
2.3 \\
24\end{array}$ & $\begin{array}{r}4.9 \\
2.7 \\
29\end{array}$ & $\begin{array}{r}4.7 \\
1.5 \\
33\end{array}$ & $\begin{array}{l}5.1 \\
48 \\
28\end{array}$ & $\begin{array}{l}4.4 \\
47 \\
23\end{array}$ & $\begin{array}{r}4.4 \\
0.0 \\
139\end{array}$ & $\begin{array}{l}4.6 \\
0.0 \\
80\end{array}$ \\
\hline Colwell P, mg kg ${ }^{-1}$ & 45 & 18 & 170 & 80 & $\begin{array}{l}36 \\
\text { Exchan }\end{array}$ & $\begin{array}{c}24 \\
\text { reable catio }\end{array}$ & $\begin{array}{l}29 \\
\left(\mathrm{cmol}_{+}\right.\end{array}$ & $\begin{array}{c}33 \\
\mathrm{~kg}^{-1} \text { soil) }\end{array}$ & 28 & 23 & 13.9 & 8.0 \\
\hline $\mathrm{Al}$ & 0.28 & 0.12 & 0.38 & 0.46 & 0.23 & 0.32 & 0.02 & 0.06 & 0.02 & 0.19 & 0.18 & 0.09 \\
\hline $\mathrm{Mn}$ & 0.39 & 0.26 & 0.57 & 0.47 & 0.02 & 0.02 & 0.02 & 0.02 & 0.44 & 0.15 & 0.03 & 0.01 \\
\hline $\mathrm{Ca}$ & 3.47 & 4.00 & 1.82 & 0.64 & 2.88 & 1.49 & 1.95 & 0.92 & 2.38 & 0.79 & 2.31 & 1.25 \\
\hline $\mathrm{K}$ & 1.11 & 1.03 & 0.81 & 0.60 & 0.10 & 0.05 & 0.18 & 0.12 & 0.69 & 0.46 & 2.14 & 1.80 \\
\hline $\mathrm{Mg}$ & 0.97 & 1.25 & 0.26 & 0.12 & 0.43 & 0.33 & 0.48 & 0.33 & 0.16 & 0.13 & 0.83 & 0.73 \\
\hline $\mathrm{Na}$ & 0.02 & 0.02 & 0.01 & 0.01 & 0.30 & 0.15 & 0.09 & 0.03 & 0.10 & 0.10 & 0.27 & 0.18 \\
\hline Total & 6.24 & 6.68 & 3.85 & 2.30 & 3.96 & 2.36 & 2.74 & 1.48 & 3.79 & 1.82 & 5.76 & 4.06 \\
\hline $\mathrm{Al}, \%$ & 4.5 & 1.8 & 9.9 & 20.0 & 5.8 & 13.6 & 0.7 & 4.1 & 0.5 & 10.4 & 3.1 & 2.2 \\
\hline
\end{tabular}

EC: Electrical conductivity. 
Table 2. Monthly rainfall for $2005-2008$ and 30 yr long term average annual rainfall (LAR) for Wagga Wagga, Binalong, Katanning, Newdegate, Byawatha and Bealiba (Bureau of Meteorology, 2009).

\begin{tabular}{|c|c|c|c|c|c|c|c|c|c|c|c|c|c|c|c|}
\hline State & Site & Year & Jan & Feb & Mar & Apr & May & June & July & Aug & Sep & Oct & Nov & Dec & Total \\
\hline \multirow[t]{10}{*}{ NSW } & \multirow[t]{5}{*}{ Wagga Wagga } & 2005 & 18.9 & 41.0 & 7.2 & 17.6 & 5.2 & 65.5 & 51.3 & 60.6 & 81.9 & 62.8 & 23.0 & 40.9 & 475.9 \\
\hline & & 2006 & 43.2 & 4.2 & 14.0 & 6.8 & 26.4 & 63.6 & 48.6 & 6.0 & 21.4 & 4.8 & 26.3 & 7.0 & 272.3 \\
\hline & & 2007 & 19.1 & 38.2 & 23.1 & 43.2 & 50.0 & 18.9 & 39.7 & 12.9 & 5.7 & 22.8 & 41.3 & 67.4 & 382.3 \\
\hline & & 2008 & 53.8 & 47.2 & 24.8 & 20.1 & 11.8 & 32.0 & 51.5 & 24.0 & 28.2 & 16.6 & 48.9 & 54.6 & 413.5 \\
\hline & & LAR & 37.0 & 35.6 & 33.9 & 37.0 & 47.7 & 48.5 & 55.5 & 51.8 & 52.5 & 47.1 & 40.5 & 39.8 & 527.0 \\
\hline & \multirow[t]{5}{*}{ Binalong } & 2005 & 50.8 & 47.6 & 20.4 & 5.0 & 0.6 & 113.4 & 120.2 & 88.2 & 115.8 & 76.6 & 69.2 & 20.8 & 728.6 \\
\hline & & 2006 & 50.3 & 3.4 & 15.8 & 15.3 & 11.2 & 52.1 & 60.8 & 15.2 & 40.0 & 0.0 & 15.8 & 11.3 & 291.2 \\
\hline & & 2007 & 21.4 & 26.9 & 57.9 & 66.1 & 59.6 & 49.2 & 47.3 & 16.0 & 9.6 & 24.1 & 126.4 & 94.8 & 599.3 \\
\hline & & 2008 & 55.1 & 39.7 & 44.0 & 34.7 & 13.4 & 47.6 & 34.7 & 50.4 & 20.0 & 49.0 & 75.2 & 57.1 & 520.9 \\
\hline & & LAR & 43.1 & 36.2 & 45.3 & 45.6 & 53.4 & 62.9 & 74.6 & 63.3 & 62.8 & 57.4 & 58.2 & 52.3 & 655.1 \\
\hline \multirow[t]{10}{*}{ WA } & \multirow[t]{5}{*}{ Katanning } & 2005 & 1.0 & 0.8 & 36.6 & 84.8 & 162.4 & 66.6 & 28.2 & 39.8 & 50.0 & 36.0 & 35.8 & 12.8 & 554.8 \\
\hline & & 2006 & 80.8 & 2.2 & 1.0 & 35.8 & 14.6 & 17.6 & 57.6 & 60.6 & 22.2 & 13.8 & 8.4 & 1.8 & 316.4 \\
\hline & & 2007 & 20.2 & 1.0 & 7.6 & 50.2 & 18.4 & 43.4 & 87.2 & 60.4 & 49.4 & 52.2 & 2.2 & 38.8 & 431.0 \\
\hline & & 2008 & 0.2 & 0.6 & 3.6 & 64.2 & 49.0 & 64.0 & 96.0 & 8.6 & 38.6 & 50.0 & 26.0 & 20.8 & 421.6 \\
\hline & & LAR & 26.0 & 15.0 & 12.0 & 59.0 & 61.0 & 48.0 & 67.0 & 42.0 & 40.0 & 38.0 & 16.0 & 18.0 & 442.0 \\
\hline & \multirow[t]{5}{*}{ Newdegate } & 2005 & 0.0 & 3.0 & 32.4 & 18.6 & 70.0 & 65.6 & 14.6 & 31.4 & 39.4 & 39.0 & 16.0 & 5.4 & 335.4 \\
\hline & & 2006 & 151.4 & 12.0 & 31.2 & 28.2 & 4.0 & 16.2 & 32.2 & 66.0 & 28.2 & 16.2 & 28.8 & 13.4 & 427.8 \\
\hline & & 2007 & 29.2 & 0.0 & 0.2 & 33.8 & 18.2 & 43.2 & 64.0 & 32.2 & 23.6 & 38.6 & 0.4 & 47.4 & 330.8 \\
\hline & & 2008 & 0.2 & 25.8 & 3.4 & 50.6 & 51.2 & 44.6 & 91.4 & 11.6 & 61.0 & 89.6 & 36.0 & 63.0 & 528.4 \\
\hline & & LAR & 23.0 & 14.0 & 15.0 & 20.0 & 38.0 & 41.0 & 46.0 & 38.0 & 31.0 & 21.0 & 17.0 & 14.0 & 318.0 \\
\hline \multirow[t]{10}{*}{ Victoria } & \multirow[t]{5}{*}{ Byawatha } & 2005 & 45.0 & 182.5 & 12.5 & 8.5 & 6.0 & 122.5 & 73.5 & 101.5 & 76.0 & 101.0 & 73.5 & 46.5 & 849.0 \\
\hline & & 2006 & 9.5 & 14.5 & 21.5 & 34.5 & 26.5 & 32.5 & 57.0 & 22.5 & 33.5 & 1.5 & 44.0 & 4.0 & 301.5 \\
\hline & & 2007 & 16.8 & 34.8 & 52.5 & 40.8 & 111.0 & 49.5 & 74.0 & 11.5 & 13.3 & 20.5 & 38.0 & 49.0 & 511.5 \\
\hline & & 2008 & 59.0 & 29.0 & 22.5 & 20.0 & 44.0 & 18.5 & 97.5 & 53.8 & 25.5 & 9.5 & 82.5 & 53.8 & 515.5 \\
\hline & & LAR & 43.1 & 38.0 & 35.1 & 43.2 & 57.2 & 59.3 & 67.4 & 67.2 & 60.5 & 58.8 & 50.2 & 40.7 & 619.5 \\
\hline & \multirow[t]{5}{*}{ Bealiba } & 2005 & 32.6 & 72.6 & 3.8 & 21.4 & 12.6 & 84.9 & 30.2 & 56.8 & 41.8 & 46.6 & 32.6 & 53.8 & 489.7 \\
\hline & & 2006 & 33.2 & 2.2 & 12.4 & 32.0 & 26.4 & 23.2 & 69.3 & 15.0 & 28.2 & 0.8 & 13.8 & 18.4 & 274.9 \\
\hline & & 2007 & 60.4 & 14.6 & 20.8 & 34.8 & 87.4 & 27.6 & 40.2 & 8.6 & 26.2 & 5.0 & 56.2 & 27.2 & 409.0 \\
\hline & & 2008 & 16.0 & 8.8 & 21.0 & 8.2 & 28.4 & 23.6 & 55.8 & 29.2 & 17.0 & 5.8 & 61.1 & 57.2 & 332.1 \\
\hline & & LAR & 31.0 & 23.0 & 27.0 & 35.0 & 47.0 & 45.0 & 48.0 & 52.0 & 47.0 & 45.0 & 37.0 & 32.0 & 469.0 \\
\hline
\end{tabular}

NSW: New South Wales; WA: Western Australia.

(318 $\mathrm{mm})$. Summers at all sites are typically hot with average maximum temperatures above $29^{\circ} \mathrm{C}$ (Table 3 ). Winters are mild to cool at all sites with minimum average temperatures above $0{ }^{\circ} \mathrm{C}$, however the more elevated sites can experience up to $30 \mathrm{~d}$ of frosts per year with absolute minimum temperatures in the coldest day of the coldest month of $-7.5^{\circ} \mathrm{C}$ at Byawatha in June 2006 .

Seasonal conditions at the sites during the experimental period showed large variation in rainfall from year to year as is common in southern Australia. Some locations such as the Wagga Wagga, Byawatha and Bealiba sites also experienced prolonged periods of below average rainfall (Table 2) which severely drought stressed the germplasm with annual rainfall in some years being only $49-58 \%$ of the long term average.

\section{Selection of genera and species}

A total of 174 legume and herb entries from 103 species in 32 genera were evaluated. These entries were sourced from the Trifolium Genetic Resource Centre at the Department of Agriculture and Food, Western Australia (DAFWA), Perth, WA or the South Australian Research and Development Institute (SARDI), Adelaide, South Australia (Hughes et al., 2008) and include cultivars, selected lines and some composites of a few entries within a species (Appendix 1). Lucerne was selected as the common control species across all sites as it is the most drought hardy and widely grown of all the available perennial legumes.

The risk of introducing new weeds to the Australian environment is well recognised and all entries new to Australia underwent appropriate quarantine assessments

Table 3. Mean monthly maximum and minimum temperatures $\left({ }^{\circ} \mathrm{C}\right)$ for $2005-2008$ at each site.

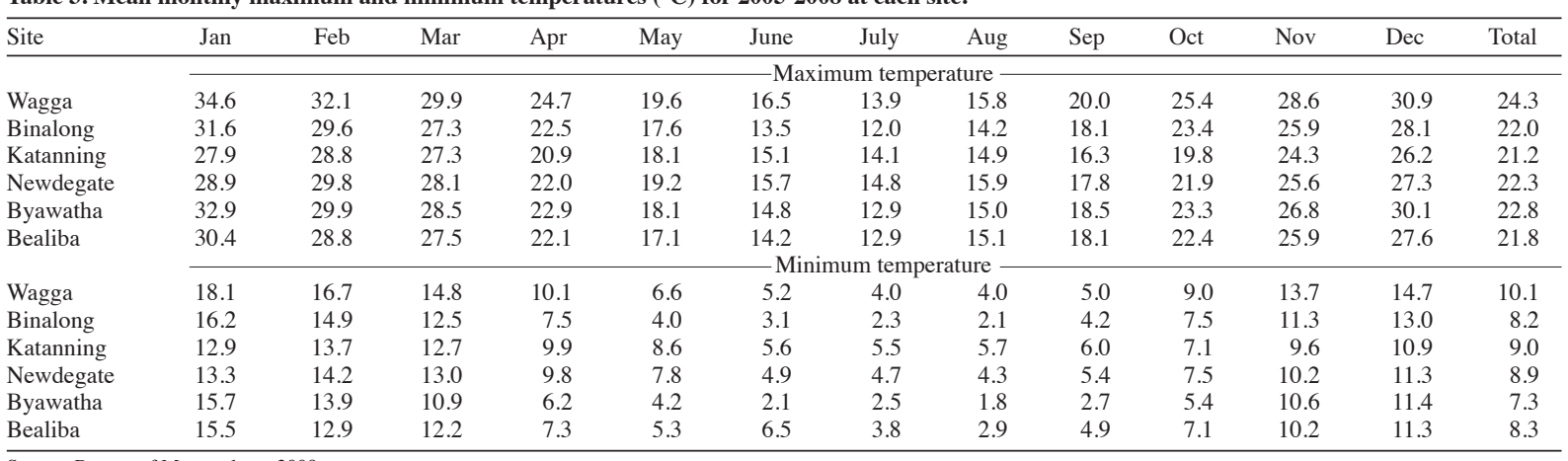

Source: Bureau of Meteorology, 2009. 
by the Australian Quarantine and Inspection Service (AQIS), the Western Australian Quarantine and Inspection Service (WAQIS), and the internal weed risk assessment scheme of the Salinity CRC (Stone et al., 2008).

A total of 102 entries were sown at Wagga Wagga and Binalong, 95 at Katanning and Newdegate, 94 at Byawatha, and 53 at Bealiba. A paucity of seed of some lines meant that not all could be sown at all sites although there were 54 entries in common at the first five sites sown. Some entries were only sown at the later sown Bealiba site as they had not passed through quarantine in time for sowing at the other sites. The entries were selected based on (a) site characteristics of their native environments (Hughes et al., 2008); (b) previous performance in other marginal environments (Real et al., 2005); (c) performance during seed increase at the SA and WA Genetic Resource Centres (Hughes et al., 2008); (d) previous field performance in WA (G. Moore, 2004, Department of Agriculture and Food Western Australia, unpublished data), and (e) relative performance in previous field studies (Li et al., 2008).

Each entry was sown into single $1 \mathrm{~m}$ long rows (plots), replicated three times, and separated by buffer pathways $1 \mathrm{~m}$ apart at Byawatha, Wagga and Binalong, $2 \mathrm{~m}$ at Katanning and Newdegate and at $0.5 \mathrm{~m}$ at Bealiba. Each plot was sown as a monocrop with $1 \mathrm{~g}$ of viable seed. Even though there was a diverse range of seed sizes within the evaluated entries, $1 \mathrm{~g}$ of seed allowed a full $1 \mathrm{~m}$ row cover for all species. Leguminous entries were inoculated with the appropriate strain of root nodule bacteria (RNB), and lime pelleted prior to sowing. Appropriate RNB were provided by the Centre for Rhizobium Studies (CRS), Murdoch University, WA; SARDI, SA or the Department of Primary Industries, Victoria (Howieson et al ., 2000). For species where an effective RNB has yet to be identified, a diverse mixture of strains was used that offered the best probability of forming an effective symbiosis. The list of strains is provided in Appendix 1.

\section{Experimental design}

A row and column design was used to restrict spatial repetition of treatments and reduce the number of treatment neighbouring concurrences in rows and columns (Cullis et al., 2006). All temperate and Mediterranean entries were sown in winter while subtropical or tropical entries were sown in spring to accommodate different temperature requirements at germination. At each site, winter and spring experiments were adjacent to each other. All entries at Bealiba were sown in winter only.

\section{Site management and measurements}

The experiments were kept weed-free by spraying the buffers with a non-selective herbicide (glyphosate, $510 \mathrm{~g}$ a.i. L ${ }^{-1}$; Nufarm Australia Ltd., Laverton North, Victoria, Australia). At the Katanning and Newdegate experimental sites weed growth in the buffer pathways were controlled by mowing when required. Weeds within the rows or close by were hand-weeded to avoid potential herbicide damage to the sown species. Starter fertilizer $(15 \% \mathrm{~N}$, $13 \% \mathrm{P}, 10 \% \mathrm{~S}$ ) was applied to the Wagga Wagga and Binalong sites at sowing at $2 \mathrm{~g}$ per row which equated to approximately $160 \mathrm{~kg} \mathrm{ha}^{-1}$. Single superphosphate $(8.8 \%$ $\mathrm{P}, 11 \% \mathrm{~S}$ ) was applied at a similar rate prior to spring in the second year to all treatments at both sites. Single superphosphate was applied at $125 \mathrm{~kg} \mathrm{ha}^{-1}$ once in early spring 2005 at Byawatha and at $200 \mathrm{~kg} \mathrm{ha}^{-1}$ at sowing and each autumn $(2007,2008)$ at Bealiba. Both the Katanning and Newdegate experimental sites were hand topdressed with $150 \mathrm{~kg} \mathrm{ha}^{-1}$ of single superphosphate and potash mixed in a ratio of 3:2 in early autumn each year.

Herbage production. All entries were assessed visually with a score of 10 as the highest and 1 as the lowest herbage DM yield at each measurement at each site. At Newdegate and Katanning all plant material from each plot was harvested, bagged, oven-dried at $60{ }^{\circ} \mathrm{C}$ for 48 $\mathrm{h}$, and then weighed to obtain herbage DM yield per row. At Wagga Wagga and Binalong, the visual DM scores were converted into herbage DM yield with appropriate calibration equations $\left(\mathrm{R}^{2}>0.90\right)$ derived from 10 representative plots at each assessment. No herbage yield calibrations were taken at Byawatha and Bealiba. Herbage production was assessed once every 3-mo, normally at the end of each season at each site. No assessment was carried out in some seasons at some sites if there was negligible growth. There were up to 13 assessments of herbage yield at each site over 3 yr. For all sites in NSW and Victoria, plots were hand cut to $5 \mathrm{~cm}$ height above ground level immediately after each assessment. The Wagga Wagga site was crashed-grazed in 1 day by sheep on two occasions to avoid any differential grazing due to animal selection.

Plant persistence. Basal frequency was assessed as plant persistence using a $0.2 \times 1.0 \mathrm{~m}$ quadrant with 50 $\times 50 \mathrm{~mm}$ grids in each autumn shortly after the initial 'breaking' rains from year 2 onwards at all sites except at Byawatha and Bealiba. Basal frequency is presented as the percentage of squares containing at least one sown perennial plant base.

\section{Data analysis}

ASReml-R (Butler et al., 2009) was used to fit a linear mixed model to each of the response variables of DM yields, visual scores, and the square root of the basal frequency. The DM yields were also transformed by $\log 10(x+1)$ to improve the normality assumptions and stabilize the variance. The winter and spring experiments were analyzed separately because the nature of the entries were mostly different for the two different sowings.

Since the number of entries is very unbalanced between the sites, we used the linear mixed model approach to predict the means for each entry (BLUPS) even though the entries may not be present at all of the sites. The 
linear mixed model takes the form of a simple nested repeated-measures model (assuming 'equal-correlation between times') as in Cochran and Cox (1957) for multienvironment trials. The model is nested as follows:

SITES/REP/PLOTS/TIMES with ENTRIES allocated at the PLOTS at random.

We considered the entries as RANDOM so therefore the means for the ENTRIES are called BLUPS or 'adjusted means'. Since the nature of the ENTRIES was quite unbalanced across the sites, the adjusted means would be expected to be shrunken towards the mean of all of the ENTRIES across all of the SITES. The only fixed factor was TIMES since the SITE has different entries it was considered as random.

We looked at the response over time but we noticed that the seasonality comparison of Winter vs. Summer as a strong component of this time response. An aspect of the time response was to consider a comparison between the winter and summer performance since this explained most of the variability in the time responses.

The summary of the responses was displayed with a graph (a 2-dimensional plot of effects) between the comparison over time of a "Winter" vs. "Summer" BLUP or adjusted mean. The graph shows a quadrant of responses where the response in the top-right hand corner represented the better entries compared to the ones in the bottom left-hand corner where the entries went to a zero end point were poor performers.

The averages of the standard errors of the BLUPS for the entries were used to construct approximate 95\% confidence interval for the mean of the BLUPS to indicate a separation of the performance of the entries relative to the mean of the entries.

For persistence data, there were only three annual time points of measurements so the TIMES factor was subjected to a simple linear trend or slope comparison across the TIMES. We examined the slopes and final basal frequency in a similar way to the above measurements but only summarised in the manuscript results without graphical display.

\section{RESULTS}

\section{Herbage yield}

Despite the different seasonal and soil conditions, the various entries had a similar performance across sites with no significant $\mathrm{G} \times \mathrm{E}$ interaction in herbage yields when determined by either herbage DM yield or visual DM scores. The only significant term in the model was Entry $(P \leq 0.05)$. There were no other significant interactions between any other terms in the model.

Herbage DM yield. A pair-wise plot of the BLUPS of the summer vs. winter BLUPs for the log transformed DM cuts is presented in Figures $1 \mathrm{a}$ and $1 \mathrm{~b}$ for the winter and spring experiments. For winter sown experiments,
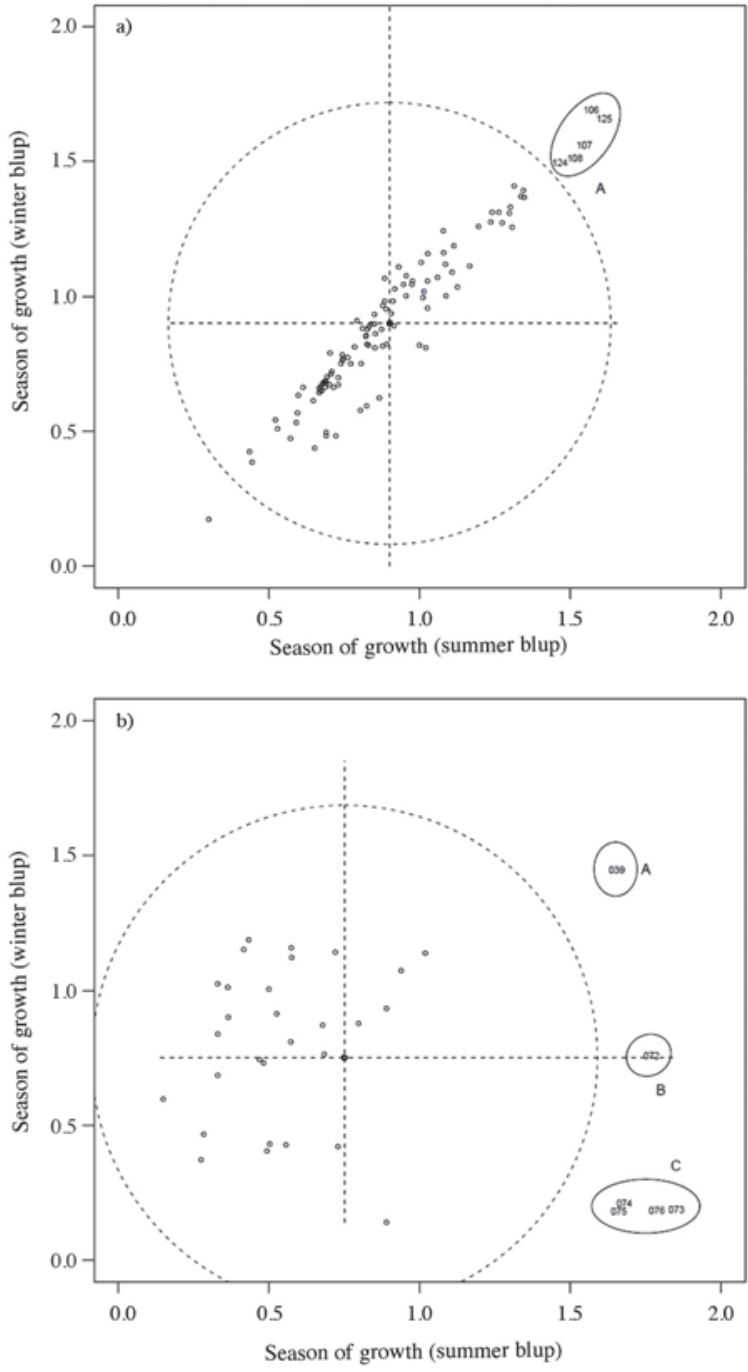

Entry numbers outside the $95 \%$ confidence interval correspond to the codes given in Appendix 1.

Entries inside the $95 \%$ confidence interval or in the left lower quadrant were represented with a circle.

Figure 1. Herbage dry matter yield (BLUPS) with a $95 \%$ confidence interval (dashed) about the mean for (a) winter sown experiments and (b) spring sown experiments.

only one cluster of entries was formed outside the $95 \%$ confidence interval central ellipse around the grand mean with the best summer and winter performance. It consists of five entries corresponding to two species, $M$. sativa subsp. sativa (codes 106, 107, and 108) and M. sativa subsp. falcata L. Arcang. (124 and 125). For spring sown experiments, cluster A had the best summer and winter performance. It consisted of only entry, C. australasicum (Schltdl.) J.W. Grimes (39). Cluster B had a very good summer production and an average winter production and consisted of Lotononis bainesii Baker (72). Cluster $\mathrm{C}$ had a very good summer production and a low winter production and consisted of 4 entries of L. bainesii (73, 74,75 , and 76). 
Herbage visual DM scores. A pair-wise plot of the BLUPS for the effects of the visual DM scores for summer and winter across the six sites is presented in Figure 2a for the winter sown experiments and Figure $2 b$ for the spring sown experiments. An ellipse representing the 95\% confidence interval from the grand mean was also plotted.

For winter sown experiments, Cluster A had the best summer and winter production. It consisted of 11 entries corresponding to six species with entry code in brackets as follows: Bituminaria bituminosa var. albomarginata C.H. Stirt (35); Cullen australasicum (39 and 40); Dorycnium hirsutum (L.) Ser. (51); Kennedia prostrata R. Br. (65); M. sativa subsp. sativa $(106,107,108$, and 117) and $M$.
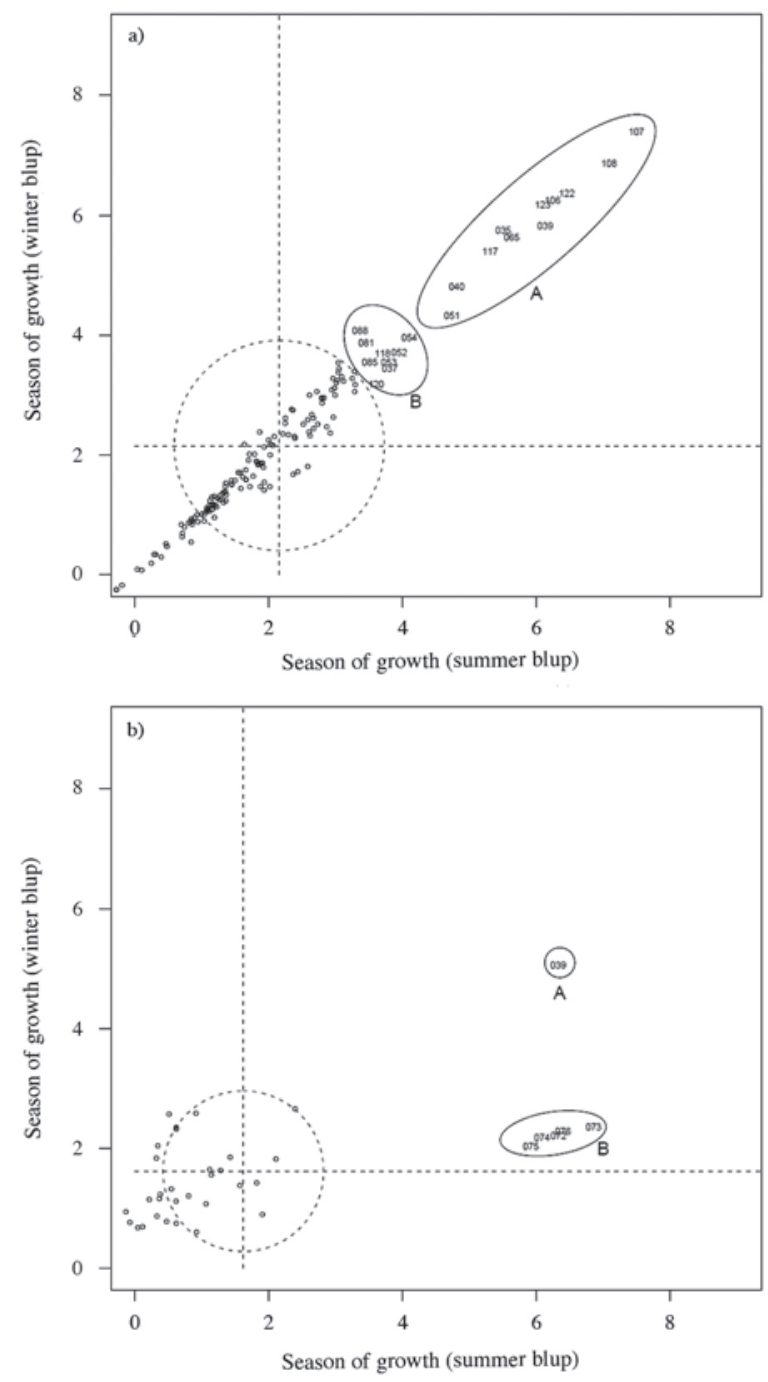

The solid ellipses A and B indicate 2 diverse clusters.

Entry numbers outside the $95 \%$ confidence interval correspond to the codes given in Appendix 1.

Entries inside the $95 \%$ confidence interval or in the left lower quadrant were represented with a circle.

Figure 2. Herbage visual dry matter scores (BLUPS) with a $95 \%$ confidence interval (dashed) about the mean for (a) winter sown experiments and (b) spring sown experiments. sativa subsp. falcata (122 and 123). Cluster B production in summer and winter was medium. It consisted of nine entries corresponding to seven species, C. intybus L. (37); D. hirsutum (52, 53, and 54); L. pedunculatus Cav. (81); L. corniculatus L. (85); L. cytisoides L. (88); M. sativa subsp. sativa (118); M. sativa subsp. caerulea (Less. ex Ledeb.) Schmalh (120).

For spring sown experiments, Cluster A had the highest summer and winter production. It consisted of only one entry of C. australasicum (39). Cluster B had a very good summer production and close to average winter production. It consists of five entries of L. bainesii (72, $73,74,75$, and 76).

From the analysis of both herbage DM yield and visual DM scores of the winter and spring experiments, 12 entries were identified as the most promising for either their winter, summer, or all-year round production as follows, B. bituminosa var. albomarginata (35); C. intybus (37); $C$. australasicum (39); D. hirsutum (51); K. prostrata (65); L. bainesii (72); L. pedunculatus (81); L. corniculatus (85); L. cytisoides (88); M. sativa subsp. sativa (107); $M$. sativa subsp. caerulea (120) and M. sativa subsp. falcata (123). The identified 12 entries maintained production for the entire experimental period, with the exception of $C$. intybus and L. corniculatus which declined in production over time.

\section{Basal frequency}

For the winter and spring sown experiments there was a significant $\mathrm{G} \times \mathrm{E}$ interaction for basal frequency assessed shortly after the "breaking" rains in years 2, 3, and 4. Therefore, results are presented for Wagga Wagga, Binalong, Katanning, and Newdegate separately.

For the winter sown experiments, 19, 1, 28, and 27 entries had above average basal frequency at Binalong, Wagga Wagga, Katanning, and Newdegate, respectively. Overall M. sativa subsp. falcata (122) was the only entry better than average at all sites. At Binalong, Katanning, and Newdegate, the following entries had superior persistence, C. australasicum (39); D. graecum Ser. (48), D. hirsutum (50, 52, 53, and 54); D. pentaphyllum Scop. (55 and 57); L. pedunculatus (81); L. cytisoides (89); $M$. sativa subsp. sativa (106, 107, and 108); M. sativa subsp. caerulea (120 and 121) and M. sativa subsp. falcata (122). At Katanning and Newdegate, the following entries had high basal frequency: D. graecum (49), D. hirsutum (51); D. pentaphyllum (56); L. creticus (87); L. cytisoides (88); L. tenuis Willd. (93) and T. tumens M. Bieb (171). Lotus corniculatus (92) had high basal frequency at Binalong and Newdegate. Trifolium ambiguum M. Bieb (158) was superior at the higher rainfall Binalong site whereas Lotus corniculatus (82) and T. physodes M. Bieb. (167, 168, and 169) performed best at Katanning. Argyrolobium uniflorum Jaub. \& Spach. (9 and 10); H. boutignyanum Alleiz. (63) and M. suffruticosa DC (124) had superior persistence at Newdegate. 
For the spring sown experiments, 6, 8, 7, and 8 entries had better than average persistence at Wagga Wagga, Binalong, Katanning, and Newdegate, respectively. Lotononis bainesii (72 to 76 ) was within the better than average group at these four sites. Glycine canescens F.J. Herm. (60) was within this group at Katanning and Newdegate, G. tabacina Benth. (61) and Cullen tenax J.W. Grimes(44) at Newdegate, C.tenax (45) at Binalong, Cullen australasicum (39) at Wagga Wagga and Binalong (not sown in spring at Katanning and Newdegate), and Astragalus cicer L. (15) at Binalong and Desmanthus acuminatus Benth. (46) at Katanning.

\section{DISCUSSION}

The 3-yr evaluation at six sites in southern Australia identified a set of 10 priority perennial forage legumes (B. bituminosa var. albomarginata; C. australasicum; D. hirsutum; K. prostrata; L. bainesii; L. pedunculatus; L. cytisoides; $M$. sativa subsp. sativa; $M$. sativa subsp. Caerulea, and M. sativa subsp. falcata) with suitable adaptation, performance, and persistence.

Six of the top 10 entries identified in the current study $(C$. australasicum, D. hirsutum, L.cytisoides, L.pedunculatus, $M$. sativa subsp. sativa and $M$. sativa subsp. caerulea) were also ranked in the top 10 entries by Li et al. (2008), based on their forage yield in the waterlogged soil and/or acid soil environments and in environments with less soil constraints. The good performance of $C$. australasicum at a number of sites in the current study (cluster $\mathrm{A}$ in both winter and spring sown experiments, Figures $2 a, 2 b$ ) and those of Li et al. (2008) supports recent findings by Hayes et al. (2009) that found accessions of this species were the most promising of the four Cullen species they evaluated, with persistence in grazed swards equivalent to lucerne. The lower palatability of $C$. australasicum observed in some field studies (Hayes et al., 2009) suggests it could have a niche in lower rainfall regions where set stocking and large paddock sizes restrict the ability to implement rotational grazing. Cullen australasicum performed well in both winter and spring sown experiments in the current study suggesting it establishes readily in cooler conditions despite being most active in the warmer months.

The appearance of the two perennial Medicago subspecies sativa and caerulea in the top groups (cluster $\mathrm{A}$ and $\mathrm{B}$ ) is supported by a recent study by Li et al. (2010b) of a diverse range of germplasm from the $M$. sativa complex in similar environments to the current study. They found that subspecies sativa was superior in terms of both persistence and productivity in less moisture stressed environments but unselected accessions of subspecies caerulea demonstrated persistence equivalent to the control lucerne cultivar Sceptre in drier environments ( $\mathrm{Li}$ et al., 2010b). Medicago sativa subsp. caerulea is found in the drier regions of the natural distribution of the $M$. sativa complex (Small, 2003) and hence this subspecies is the most likely to yield highly drought tolerant germplasm and should be further exploited for semi arid Mediterranean environments. A third member of the $M$. sativa complex, $M$. sativa subsp. falcata also fell within the best performing species group in the current study. This species occupies the more northern range of the $M$. sativa complex in its natural environment and is regarded as very cold and drought hardy and more able to tolerate acid soils (Small, 2003). However the recent study by Li et al. (2010b) at three locations in eastern Australia found the falcata subspecies to be far less productive than subspecies sativa, caerulea and varia.

Lotononis bainseii was another species in the high priority cluster B group (Figure 2b) in the spring sown experiments. Lotononis bainseii had superior basal frequency scores at four sites reflecting the ability of this stoloniferous species to cover the ground surface. The use of this subtropical species has, to date, been restricted in southern Australia by unreliable establishment from seed and very specific seed bed and temperature requirements for emergence (Blumenthal and Hilder, 1989). Poor seedling establishment has also been a major factor in reducing adoption of the species in Uruguay (D. Real, 2008 personal communication). This species requires warm temperatures for growth $\left(>9{ }^{\circ} \mathrm{C}\right)$ and hence its productivity relies on sufficient rainfall in late spring and early summer when temperatures are most suitable for its growth. Its requirement for warmer temperatures for growth is reflected by its superior DM scores during summer in the current study (cluster B, Figure 2b).

The Lotus genus had a number of species listed within the high priority cluster B group (Figure 2a), namely $L$. corniculatus, L. pedunculatus and L.cytisoides. Since this study commenced, significant progress has been reported in breeding new cultivars of L. corniculatus with greatly improved flowering and seed production at lower latitudes similar to the experimental sites of the current study (D. Real, 2007 personal communication).

The identification of B. bituminosa var. albomarginata (35) in the current study as a species of high potential (Cluster A, Figure 2a) demonstrates that it is still possible to identify new prospective species that offer valuable adaptive characteristics that can be exploited. Early studies conducted in the Canary Islands (Mendez et al., 2006) and in Italy (Pagnotta et al., 2003) also showed the promising potential of this species in Mediterranean environments. It demonstrates a high level of drought and grazing tolerance in its native environments in the Mediterranean basin and the Canary Islands (Gutman et al., 2000; Muñoz et al., 2000). It is reported to be tolerant of grazing by cattle (Sternberg et al., 2006) and goats (Ventura et al., 2000). There is substantial genetic variation within the species with $B$. bituminosa var. albomarginata found in coastal semi arid environments (average annual rainfall 150-300 $\mathrm{mm}$ ) but other varieties, such as var. crassiuscula, are found in high elevation (1700-2200 m) sub humid 500 
mm rainfall environments (Muñoz et al., 2000; Real et al., 2009). An important attribute of this species is that unlike lucerne it retains its leaves when moisture stressed, therefore providing valuable feed over summer (Real and Verbyla, 2010).

The remaining two leguminous species in the top group were $D$. hirsutum and $K$. prostrata. Dorycnium hirsutum originates in the Mediterranean region and is distributed from the Canary Islands to the Balkans (Bennett, 2003). High levels of condensed tannins and low reliability of establishment are two of the current limitations of Dorycnium species identified by Bell et al. (2008). Less is known about the Australian native perennial legume $K$. prostrata. Recent studies have found it to be more productive under low $\mathrm{P}$ conditions than lucerne (Pang et al., 2010), achieving maximum growth at $12 \mathrm{mg} \mathrm{P} \mathrm{kg}^{-1}$ soil compared to an optimum of $24 \mathrm{mg}$ $\mathrm{P} \mathrm{kg}^{-1}$ for lucerne. This low $\mathrm{P}$ requirement most likely reflects its adaptation to the low $\mathrm{P}$ status of soils in its native environment and a root distribution that enhances $\mathrm{P}$ acquisition (Denton et al., 2006). The attractiveness of this species as a forage may be limited by the quality of its herbage. Analysis of herbage quality of the related species $K$. prorepens found high levels of condensed tannins (10$\left.18 \mathrm{~g} \mathrm{~kg}^{-1} \mathrm{DM}\right)$ and relatively low crude protein (12\%) and in vitro digestibility (55\%) values (Robertson et al., 2007). Kennedia prostrata was only evaluated at one site, Bealiba, and its potential cannot be properly assessed until its performance is determined at a greater range of sites and herbage quality is better documented.

Cichorium intybus was the only non leguminous species to fall within the priority groups (cluster B, Figure 2a) in the current study. This species has performed well in less stressful New Zealand environments ( $\mathrm{Li}$ and Kemp, 2005) and in a number of recent studies in southern Australia (Li et al., 2008; Reed et al., 2008; Li et al., 2010a), but it is relatively short lived in drier environments. The productivity declined progressively in the current study. Its poor performance in drier environments is not unexpected given that no cultivars of this species have been developed specifically for low rainfall environments. Further selection to exploit the large genetic diversity within this species is warranted for increased persistence in lower rainfall environments.

For forage legumes to perform to their potential under field conditions, an effective symbiosis is essential to provide adequate biologically fixed $\mathrm{N}$ to the plant (Howieson et al., 2000). All leguminous species evaluated were inoculated with either commercial or experimental inoculants that were the best inoculant with the information available at the time of sowing. It is acknowledged that some non commercialized species may not have highly effective RNB available as until they demonstrate significant agronomic potential it is difficult to justify the intensive research required to identify superior inoculants. The lack of well adapted RNB for non domesticated species is always a restriction when evaluating wild or non commercial species.

A second group of 15 entries (A. uniflorum, A. cicer, C.tenax, D. acuminatus, D. graecum, D. pentaphyllum, G. canescens, G. tabacina, $H$. boutignyanum, $L$. corniculatus, L. tenuis, M. suffruticosa, T. ambiguum, $T$. physodes, and T. tumens) was identified for their good persistence across sites or at particular sites. Although this group may lack productivity, their persistence, often under severely drought stressed growing conditions, warrants further selection to identify more productive genotypes as the majority of these have undergone little agronomic selection.

For any of these selected species to be successful on a commercial scale there are several other characteristics that need to be considered in their development. As a minimum they would be required to i) have a broad soil and climatic adaptation to help promote a large seed market; ii) have a reliable seed establishment and the necessary seedling vigour; iii) have high seed yields and can be cost effectively harvested with a final seed cost that can compete favourably with alternative existing forage options; iv) have good grazing tolerance; v) have good seasonal forage quality especially outside the annual growing season when it is most valuable to support an animal industry; vi) have no adverse effect on animal health or risks (such as bloat) and be managed effectively with grazing. Some of the more promising species identified are being studied further by the Future Farm Industries Cooperative Research Centre (previously Salinity CRC) as new forage perennial pasture options for farmers in Mediterranean climatic zones.

\section{CONCLUSIONS}

The evaluation of a broad range of species supported the hypothesis that there are herbaceous perennials not currently utilised in Australia that are sufficiently persistent and productive under Australian field conditions to warrant further development for use in Mediterraneanlike climate agriculture. The promising species identified based on herbage production were B. bituminosa var. albomarginata, $C$. australasicum, D. hirsutum, $K$. prostrate, L. bainesii, L. pedunculatus, L. cytisoides, $M$. sativa subsp. sativa, $M$. sativa subsp. caerula, and $M$. sativa subsp. falcata. These species require further study to exploit their potential development as new forage perennial pasture options.

\section{ACKNOWLEDGEMENTS}

The authors wish to thank R. Snowball and S.J. Hughes for providing the seed for these experiments. We would also like to acknowledge the contributions of Justin Tidd and Craig Lihou (NSW) and David Pearce, Bron Clark, and Jamie Smith (Victoria) for their assistance in the field 
work. The project received financial support from the Grains Research and Development Corporation through the CRC for Plant-based management of Dryland Salinity.

Evaluación de leguminosas y hierbas forrajeras perennes en seis medioambientes mediterráneos. Existe una escasez de leguminosas y hierbas perennes herbáceas además de alfalfa (Medicago sativa L.) tolerantes a sequía para ambientes con clima mediterráneo como los que se encuentran en el Sur de Australia, el Mediterráneo y Chile. Por lo tanto, una colección de 174 leguminosas perennes y hierbas correspondientes a 103 especies y 32 géneros fue evaluada por su adaptación a un diverso rango de climas mediterráneos en el Sur de Australia. La distribución de las precipitaciones en los sitios experimentales varían desde moderada a altamente invernales, con un promedio de precipitaciones anuales de $318 \mathrm{~mm}$ a $655 \mathrm{~mm}$. Las accesiones fueron evaluadas por su productividad y persistencia en un período de 3 años. Las 12 accesiones identificadas como las más promisorias por su producción invernal, estival o anual fueron Bituminaria bituminosa (L.) C.H. Stirt. var. albomarginata; Cichorium intybus L.; Cullen australasicum (Schltdl.) J.W. Grimes; Dorycnium hirsutum (L.) Ser.; Kennedia prostrata R. Br.; Lotononis bainesii Baker, Lotus pedunculatus Cav.; L. corniculatus L.; L. cytisoides L.; Medicago sativa subsp. sativa L.; Medicago sativa subsp. caerulea (Less. ex Ledeb.) Schmalh., y M. sativa subsp. falcata (L.) Arcang. Estas accesiones mantuvieron la productividad y persistencia durante el período de evaluación, con la excepción de C. intybus y L. corniculatus que no persistieron. El rol potencial de estas especies en sistemas de producción extensivos en zonas de clima mediterráneo, sus ventajas y desventajas y el estado actual de desarrollo de las mismas es presentado en este trabajo.

Palabras clave: Bituminaria, Lotus, rendimiento de forraje, persistencia de leguminosas, germoplasma nativo australiano.

Appendix 1. Perennial legumes evaluated at Wagga Wagga (1) and Binalong (2), New South Wales; Katanning (3) and Newdegate (4), Western Australia and Byawatha (5) and Bealiba (6), Victoria from 2005 to 2008. Entry was sown in winter (W) or spring (S) and inoculated with appropriate root nodule bacteria (RNB).

\begin{tabular}{|c|c|c|c|c|c|c|c|c|c|c|}
\hline Code & Genera/Species & Entry & 1 & 2 & 3 & 4 & 5 & 6 & $\begin{array}{l}\text { Time of } \\
\text { sowing }\end{array}$ & RNB \\
\hline 1 & Adesmia $\mathrm{sp} 1$ & SA33599 & 1 & 1 & 1 & 1 & 1 & & $\mathrm{~W}$ & Mix 7 \\
\hline 2 & A. mucronata Hook. \& Arn. & SA33602 & 1 & 1 & & & 1 & & $\mathrm{~W}$ & Mix 7 \\
\hline 3 & A. muricata (Jacq.) DC & SA22024 & 1 & 1 & 1 & 1 & 1 & & W & Mix 7 \\
\hline 4 & A.punctata (Poir.) DC & SA33605 & 1 & 1 & 1 & 1 & 1 & & W & Mix 7 \\
\hline 5 & Adesmia $\mathrm{sp} 2$ & SA33593 & 1 & 1 & & & 1 & & $\mathrm{~W}$ & Mix 7 \\
\hline 6 & Aeschynomene falcata (Poir.) DC & ATF2196 & 1 & 1 & 1 & 1 & 1 & & $\mathrm{~S}$ & Mix 7 \\
\hline 7 & Anthyllis vulneraria $\mathrm{L}$. & SA 35244 & 1 & 1 & 1 & 1 & 1 & & $\mathrm{~W}$ & Mix 7 \\
\hline 8 & A. vulneraria $\mathrm{L}$. & SA36132 & & & 1 & 1 & & & $\mathrm{~W}$ & Mix 7 \\
\hline 9 & Argyrolobium uniflorum Jaub. \& Spach. & WA123410 & 1 & 1 & 1 & 1 & 1 & & $\mathrm{~W}$ & Mix 7 \\
\hline 10 & A. uniflorum Jaub. \& Spach. & WA12345 & & & 1 & 1 & & & $\mathrm{~W}$ & Mix 7 \\
\hline 11 & Astragalus adsurgens Pall. & SA17720 & 1 & 1 & & & 1 & & $\mathrm{~S}$ & Mix 1 \\
\hline 12 & A. aleppicus Boiss. & SA33904 & 1 & 1 & & & 1 & & $\mathrm{~S}$ & Mix 1 \\
\hline 13 & A. atropilosulus Bunge & SA32263 & 1 & 1 & & & 1 & & $\mathrm{~W}$ & Mix 1 \\
\hline 14 & A. cicer $\mathrm{L}$. & SA38090 & & & 1 & 1 & & & W & Mix 1 \\
\hline 15 & A. cicer $\mathrm{L}$. & SA38091 & 1 & 1 & 1 & 1 & 1 & & $\mathrm{~W}+\mathrm{S}$ & Mix 1 \\
\hline 16 & A. crotalariae A. Gray & SA33691 & 1 & 1 & & & 1 & & S & Mix 1 \\
\hline 17 & A. galegiformis $\mathrm{L}$. & SA33820 & 1 & 1 & & & 1 & 1 & $\mathrm{~W}+\mathrm{S}$ & Mix 1 \\
\hline 18 & A. glycyphyllos L. & SA38093 & 1 & 1 & 1 & 1 & 1 & & $W+S$ & Mix 1 \\
\hline 19 & A. nothoxys A. Gray & SA33698 & 1 & 1 & & & 1 & & W & Mix 1 \\
\hline 20 & A. onobrychis $\mathrm{L}$. & SA12667 & 1 & 1 & & & 1 & & $\mathrm{~W}$ & Mix 1 \\
\hline 21 & A.palaestinus Eig. & SA30484 & 1 & 1 & & & 1 & & W & Mix 1 \\
\hline 22 & A. refractus Boiss. \& Buhse & SA34026 & 1 & 1 & & & 1 & 1 & $W+S$ & Mix 1 \\
\hline 23 & A. siliquosus Boiss. & SA34038 & 1 & 1 & 1 & 1 & 1 & & W & Mix 1 \\
\hline 24 & A. siliquosus Boiss. & SA34039 & & & 1 & 1 & & & W & Mix 1 \\
\hline 25 & A. sinicus $\mathrm{L}$. & SA33929 & 1 & 1 & & & 1 & 1 & $W+S$ & Mix 1 \\
\hline 26 & Astragalus sp11 & Composite1 & 1 & 1 & & & 1 & & $\mathrm{~S}$ & Mix 1 \\
\hline 27 & Astragalus sp9 & Composite2 & 1 & 1 & & & 1 & 1 & $W+S$ & Mix 1 \\
\hline 28 & A. stipulosus Boriss. & SA34045 & 1 & 1 & & & 1 & & W & Mix 1 \\
\hline 29 & A. suberosus Banks \& Sol. & Composite 3 & 1 & 1 & & & 1 & & $\mathrm{~S}$ & Mix 1 \\
\hline 30 & A. suberosus Banks \& Sol. & SA16094 & & & 1 & 1 & & & $\mathrm{~W}$ & Mix 1 \\
\hline 31 & A. suberosus Banks \& Sol. & SA16095 & & & 1 & 1 & & & W & Mix 1 \\
\hline 32 & A.thurberi A. Gray & SA33700 & 1 & 1 & & & 1 & & $\mathrm{~W}$ & Mix 1 \\
\hline 33 & A.wootonii E. Sheld & SA33701 & 1 & 1 & & & 1 & & $\mathrm{~W}$ & Mix 1 \\
\hline 34 & Bituminaria bituminosa (L.) C.H. Stirt & SA36033 & 1 & 1 & & & 1 & & W & CB 2080 \\
\hline 35 & B. bituminosa var. albomarginata C.H. Stirt & PNF22A15 & & & & & & 1 & $\mathrm{~W}$ & CB 2080 \\
\hline 36 & B. bituminosa var. albomarginata C.H. Stirt & PNF33A2 & & & & & & 1 & $\mathrm{~W}$ & CB 2080 \\
\hline 37 & Cichorium intybus ${ }^{1} \mathrm{~L}$. & Puna & & & & & & 1 & $\mathrm{~W}$ & NA \\
\hline 38 & Coronilla grandiflora Willd. & SA33705 & 1 & 1 & & & 1 & & W & CC1107/CC401 \\
\hline 39 & Cullen australasicum (Schltd1.) J.W. Grimes & SA4966 & 1 & 1 & 1 & 1 & 1 & & $\mathrm{~W}+\mathrm{S}$ & Mix 2 \\
\hline 40 & C. australasicum (Schltdl.) J.W. Grimes & SA42965 & & & & & & 1 & W & Mix 2 \\
\hline 41 & C. parvum J.W. Grimes & SA40356 & & & & & & 1 & $\mathrm{~W}$ & Mix 2 \\
\hline 42 & C.patens J.W. Grimes & $\mathrm{CB} 02 \mathrm{CS}$ & & & & & & 1 & $\mathrm{~W}$ & Mix 2 \\
\hline 43 & C. patens J.W. Grimes & SA42565 & & & & & & 1 & W & Mix 2 \\
\hline 44 & C.tenax J.W. Grimes & NIND008 & 1 & 1 & 1 & 1 & 1 & 1 & $\mathrm{~W}+\mathrm{S}$ & Mix 2 \\
\hline
\end{tabular}




\begin{tabular}{|c|c|c|c|c|c|c|c|c|c|c|}
\hline Code & Genera/Species & Entry & 1 & 2 & 3 & 4 & 5 & 6 & $\begin{array}{l}\text { Time of } \\
\text { sowing }\end{array}$ & RNB \\
\hline 45 & C.tenax J.W. Grimes & SA35778 & 1 & 1 & 1 & 1 & 1 & 1 & $\mathrm{~W}+\mathrm{S}$ & Mix 2 \\
\hline 46 & Desmanthus acuminatus Benth. & 78383 & 1 & 1 & 1 & 1 & 1 & 1 & $\mathrm{~W}+\mathrm{S}$ & CB3126 \\
\hline 47 & D. virgatus Willd. & 85177 & 1 & 1 & 1 & 1 & 1 & 1 & $\mathrm{~W}+\mathrm{S}$ & CB3126 \\
\hline 48 & D. graecum Ser. & SA35667 & & & 1 & 1 & & & W & CC856 \\
\hline 49 & D. graecum Ser. & SA36069 & 1 & 1 & 1 & 1 & 1 & 1 & W & $\mathrm{CC} 856$ \\
\hline 50 & D. hirsutum (L.) Ser. & 9314 & & & 1 & 1 & & & W & CC856 \\
\hline 51 & D. hirsutum (L.) Ser. & AL3343 & 1 & 1 & 1 & 1 & 1 & 1 & W & CC856 \\
\hline 53 & D. hirsutum (L.) Ser. & AL4598 & & & 1 & 1 & & & W & CC856 \\
\hline 54 & D. hirsutum (L.) Ser. & SA36131 & & & 1 & 1 & & & W & $\mathrm{CC} 856$ \\
\hline 55 & D. pentaphyllum Scop. & SA33723 & & & 1 & 1 & & & W & CC856 \\
\hline 56 & D. pentaphyllum Scop. & SA33721 & 1 & 1 & 1 & 1 & 1 & 1 & W & CC856 \\
\hline 57 & D. pentaphyllum Scop. & Tas 1273 & & & 1 & 1 & & & W & CC856 \\
\hline 58 & Galega officinalis L. & PI251825 & 1 & 1 & 1 & 1 & 1 & 1 & W & WSM2699 \\
\hline 59 & G. officinalis $\mathrm{L}$. & VIR28855 & 1 & 1 & 1 & 1 & 1 & & W & WSM2699 \\
\hline 60 & Glycine canescens F.J. Herm. & Composite 4 & 1 & 1 & 1 & 1 & 1 & & $\mathrm{~S}$ & CC1604/13 \\
\hline 63 & Hedysarum boutignyanum Alleiz. & SA 13265 & 1 & 1 & 1 & 1 & 1 & & $\mathrm{~W}$ & WSM1592 \\
\hline 64 & Kennedia prorepens F. Muell. & KIMS001 & 1 & 1 & 1 & 1 & 1 & & W & Mix 7 \\
\hline 65 & K. prostrata $\mathrm{R} . \mathrm{Br}$. & HR001 & & & & & & 1 & W & Mix 7 \\
\hline 66 & Lespedeza juncea Pers. & AL2180 & & & 1 & 1 & & & W & $\mathrm{CC} 497 / 8$ \\
\hline 67 & L. juncea Pers. & AL489 & & & 1 & 1 & & & W & CC497/8 \\
\hline 68 & L. juncea Pers. & AUGRAZIER & & & 1 & 1 & & & W & CC497/8 \\
\hline 69 & L. juncea Pers. & AULOTAN & 1 & 1 & 1 & 1 & 1 & 1 & W & CC497/8 \\
\hline 70 & L. juncea Pers. & INTERSTATE & & & 1 & 1 & & & W & CC497/8 \\
\hline 71 & L. juncea Pers. & SA22026 & & & & & & 1 & W & CC497/8 \\
\hline 72 & Lotononis bainesii Baker & B63101 & 1 & 1 & 1 & 1 & 1 & 1 & $W+S$ & CB376 \\
\hline 73 & L. bainesii Baker & $\mathrm{B} 662 \mathrm{~S} 1$ & & & 1 & 1 & & & S & CB376 \\
\hline 74 & L. bainesii Baker & CPI49182 & & & 1 & 1 & & & $\mathrm{~S}$ & CB376 \\
\hline 75 & L. bainesii Baker & Miles & & & 1 & 1 & & & $\mathrm{~S}$ & CB376 \\
\hline 76 & L. bainesii Baker & PI224983 & & & 1 & 1 & & & $\mathrm{~S}$ & CB376 \\
\hline 77 & Lotus aegaeus Boiss. & SA37124 & 1 & 1 & & & 1 & 1 & W & Mix 3 \\
\hline 78 & Lotus australis Andrews & SA17132 & 1 & 1 & 1 & 1 & 1 & & W & Mix 3 \\
\hline 79 & L. australis Andrews & SA33610 & & & 1 & 1 & & 1 & W & Mix 3 \\
\hline 82 & L. corniculatus L. & SA32863 & 1 & 1 & 1 & 1 & 1 & & W & Mix 3 \\
\hline 83 & L. corniculatus $\mathrm{L}$. & SA25270 & 1 & 1 & 1 & 1 & 1 & & W & Mix 3 \\
\hline 84 & L. corniculatus L. & Goldie & & & & & & 1 & W & Mix 3 \\
\hline 85 & L. corniculatus L. & San Gabriel & & & & & & 1 & $\mathrm{~W}$ & Mix 3 \\
\hline 86 & L. creticus L. & SA2317 & & & 1 & 1 & & & W & Mix 3 \\
\hline 87 & L. creticus L. & SA37654 & 1 & 1 & 1 & 1 & 1 & 1 & W & Mix 3 \\
\hline 88 & L. cytisoides L. & SA12951 & 1 & 1 & 1 & 1 & 1 & 1 & W & Mix 3 \\
\hline 89 & L. cytisoides L. & SA27513 & & & 1 & 1 & & & W & Mix 3 \\
\hline 90 & L. discolor E. Mey. & SA38069 & 1 & 1 & & & 1 & & W & Mix 3 \\
\hline 91 & L. gebelia Vent. & SA 13750 & 1 & 1 & 1 & 1 & 1 & & W & Mix 3 \\
\hline 92 & L. corniculatus L. & SA833 & & & 1 & 1 & & & W & Mix 3 \\
\hline 93 & L.tenuis Willd. & SA25285 & 1 & 1 & 1 & 1 & 1 & & W & Mix 3 \\
\hline 94 & L. krylovii Schischkin \& Serg. & SA37754 & 1 & 1 & & & 1 & & W & Mix 3 \\
\hline 95 & L. palustris Vell. & SA37668 & 1 & 1 & & & 1 & 1 & W & Mix 3 \\
\hline 96 & L. pedunculatus Cav. & SA37149 & 1 & 1 & 1 & 1 & 1 & & W & Mix 3 \\
\hline 97 & L. pedunculatus Cav. & SA 26851 & 1 & 1 & 1 & 1 & 1 & & W & Mix 3 \\
\hline 98 & L. pedunculatus Cav. & Maku & & & & & & 1 & W & Mix 3 \\
\hline 99 & L. pedunculatus Cav. & Sharnae & & & & & & 1 & W & Mix 3 \\
\hline 100 & L. preslii Ten. & SA 37962 & 1 & 1 & & & 1 & 1 & W & Mix 3 \\
\hline 101 & Lotus sp1 & SA 34094 & 1 & 1 & & & 1 & & W & Mix 3 \\
\hline 102 & Lotus sp2 & SA38011 & 1 & 1 & & & 1 & & W & Mix 3 \\
\hline 103 & Medicago lupulina $\mathrm{L}$. & SA38557 & 1 & 1 & 1 & 1 & 1 & & W & Mix 4 \\
\hline 104 & M. marina $\mathrm{L}$. & SA2525 & 1 & 1 & & & 1 & & W & Mix 4 \\
\hline 105 & M. papillosa Boiss. & SA32531 & 1 & 1 & & & 1 & & W & Mix 4 \\
\hline 106 & M. sativa subsp. sativa $\mathrm{L}$. & Sceptre & 1 & 1 & 1 & 1 & 1 & 1 & W & Mix 4 \\
\hline 107 & M. sativa subsp. sativa $\mathrm{L}$. & SA38082 & & & 1 & 1 & & & W & Mix 4 \\
\hline 108 & M. sativa subsp. sativa $\mathrm{L}$. & SA41650 & & & 1 & 1 & & & W & Mix 4 \\
\hline 109 & M. sativa subsp. varia Martyn & Cancreep & & & & & & 1 & W & Mix 4 \\
\hline 110 & M. sativa subsp. caerulea (Less. ex Ledeb.) Schmalh. & Jindera & & & & & & 1 & W & Mix 4 \\
\hline 111 & M. sativa subsp. sativa $\mathrm{L}$. & SA43484 & & & & & & 1 & W & Mix 4 \\
\hline 112 & M. sativa subsp. sativa $\mathrm{L}$. & SA43485 & & & & & & 1 & W & Mix 4 \\
\hline 113 & M. sativa subsp. sativa $\mathrm{L}$. & SA43486 & & & & & & 1 & W & Mix 4 \\
\hline 114 & M. sativa subsp. sativa $\mathrm{L}$. & SA43492 & & & & & & 1 & W & Mix 4 \\
\hline 115 & M. sativa subsp. sativa $\mathrm{L}$. & SA43493 & & & & & & 1 & W & Mix 4 \\
\hline 116 & $M$. sativa subsp. sativa $\mathrm{L}$. & SA43497 & & & & & & 1 & W & Mix 4 \\
\hline
\end{tabular}




\begin{tabular}{|c|c|c|c|c|c|c|c|c|c|c|}
\hline Code & Genera/Species & Entry & 1 & 2 & 3 & 4 & 5 & 6 & $\begin{array}{l}\text { Time of } \\
\text { sowing }\end{array}$ & RNB \\
\hline 120 & M. sativa subsp. caerulea Ledeb. & SA36317 & 1 & 1 & 1 & 1 & 1 & & $\mathrm{~W}$ & Mix 4 \\
\hline 121 & M. sativa subsp. caerulea Ledeb. & SA38052 & & & 1 & 1 & & & W & Mix 4 \\
\hline 122 & M. sativa subsp. falcata (L.) Arcang. & SA32090 & & & 1 & 1 & & & W & Mix 4 \\
\hline 123 & M. sativa subsp. falcata (L.) Arcang & SA32091 & 1 & 1 & 1 & 1 & 1 & & W & Mix 4 \\
\hline 124 & M. suffruticosa DC & SA6529 & 1 & 1 & 1 & 1 & 1 & & W & Mix 4 \\
\hline 125 & Melilotus polonicus Pall. & SA36977 & 1 & 1 & & & 1 & & W & Mix 4 \\
\hline 126 & Onobrychis arenaria DC & SA34674 & 1 & 1 & & & & & W & Mix 5 \\
\hline 127 & O. arenaria $\mathrm{DC}$ & SA34700 & & & & & 1 & & W & Mix 5 \\
\hline 128 & O. armena Boiss \& A. Huet & SA32454 & 1 & 1 & & & & & W & Mix 5 \\
\hline 129 & O. armena Boiss \& A. Huet & SA32455 & & & & & 1 & & W & Mix 5 \\
\hline 130 & O. inermis Steven & Composite 5 & 1 & 1 & & & & & W & Mix 5 \\
\hline 131 & O. tanaitica Spreng. & SA38891 & 1 & 1 & 1 & 1 & & & W & Mix 5 \\
\hline 132 & O. tanaitica Spreng. & SA38956 & & & & & 1 & & W & Mix 5 \\
\hline 133 & O. tanaitica Spreng. & PA39 & & & & & & 1 & W & Mix 5 \\
\hline 134 & O. viciifolia Scop. & SA33874 & 1 & 1 & 1 & 1 & 1 & & W & Mix 5 \\
\hline 135 & O. viciifolia Scop. & Othello & & & & & & 1 & $\mathrm{~W}$ & Mix 5 \\
\hline 136 & Ononis intermedia sensu Auct. & SA38737 & 1 & & & & 1 & & W & Mix 7 \\
\hline 137 & Ptilotus polystachyus ${ }^{1}$ F. Muell. & Merredin & & 1 & & & & & W & NA \\
\hline 138 & Sanguisorba minor ${ }^{1}$ Scop. & 8969 & 1 & 1 & 1 & 1 & 1 & & W & NA \\
\hline 139 & S. minor ${ }^{1}$ Scop. & SA25861 & 1 & 1 & 1 & 1 & 1 & & W & NA \\
\hline 140 & S. minor ${ }^{1}$ Scop. & SA32463 & & & & & & 1 & W & NA \\
\hline 141 & Securigera varia Lassen & Tas 1322 & 1 & 1 & & & & & W & Mix 7 \\
\hline 142 & S. securidaca Degen \& Dorfl. & Composite6 & 1 & 1 & & & & & W & Mix 7 \\
\hline 143 & Stylosanthes guianensis Sw. & 11493 & 1 & 1 & 1 & 1 & 1 & & $\mathrm{~S}$ & Mix 7 \\
\hline 144 & S. mexicana Taub. & 87484 & 1 & 1 & 1 & 1 & 1 & & $\mathrm{~S}$ & Mix 7 \\
\hline 145 & S. scabra Vogel & ATF3076 & 1 & 1 & 1 & 1 & 1 & & $\mathrm{~S}$ & Mix 7 \\
\hline 146 & S. scabra Vogel & ATF3077 & & & 1 & 1 & & & $\mathrm{~S}$ & Mix 7 \\
\hline 147 & Swainsona beasleyana F. Muell & KIMS004 & & & & & 1 & 1 & $\mathrm{~W}+\mathrm{S}$ & Mix 7 \\
\hline 148 & S. canescens F. Muell & KIMSO03 & 1 & 1 & 1 & 1 & 1 & & S & Mix 7 \\
\hline 149 & S. colutoides F. Muell & NIND006 & 1 & 1 & 1 & 1 & 1 & & $\mathrm{~S}$ & Mix 7 \\
\hline 150 & S.a colutoides F. Muell & SA41398 & & & & & & 1 & W & Mix 7 \\
\hline 151 & S. cyclocarpa F. Muell & KIMSO02 & & & & & 1 & & $\mathrm{~S}$ & Mix 7 \\
\hline 152 & S. paradoxa W. Fitzg. & KIMSO02 & 1 & 1 & 1 & 1 & & & $\mathrm{~S}$ & Mix 7 \\
\hline 153 & S. purpurea Joy Thomps. & KIMS004 & 1 & 1 & 1 & 1 & & & $\mathrm{~S}$ & Mix 7 \\
\hline 154 & Swainsona sp. & NF023 & 1 & 1 & 1 & 1 & 1 & & $\mathrm{~S}$ & Mix 7 \\
\hline 155 & S. swainsoides J.M. Black & NIND005 & 1 & 1 & & & 1 & 1 & $\mathrm{~W}+\mathrm{S}$ & Mix 7 \\
\hline 156 & Tephrosia grandiflora Pers. & 930029 & 1 & 1 & 1 & 1 & 1 & & W & Mix 7 \\
\hline 157 & Tetragonolobus maritimus Roth. & SA32512 & 1 & 1 & & & 1 & & W & Mix 7 \\
\hline 158 & Trifolium ambiguum M. Bieb. & Tas38904 & 1 & 1 & & & & & W & Mix 6 \\
\hline 159 & T. burchellianum Ser. & AZ4520 & 1 & 1 & 1 & 1 & 1 & & W & Mix 6 \\
\hline 160 & T. fragiferum $\mathrm{L}$. & Palestine & & & & & & 1 & W & Mix 6 \\
\hline 161 & T. fragiferum $\mathrm{L}$. & SA38076 & & & & & & 1 & W & Mix 6 \\
\hline 162 & T. hybridum $\mathrm{L}$. & AB302 & 1 & 1 & 1 & 1 & 1 & & W & Mix 6 \\
\hline 163 & T. hybridum $\mathrm{L}$. & SA33368 & & & 1 & 1 & & & W & Mix 6 \\
\hline 164 & T. ochroleucum Huds. & AZ4257 & & & 1 & 1 & & & W & Mix 6 \\
\hline 165 & T. ochroleucum Huds. & Composite7 & 1 & 1 & 1 & 1 & 1 & & W & Mix 6 \\
\hline 166 & T. ochroleucum Huds. & Tas433J502 & 1 & 1 & & & & & W & Mix 6 \\
\hline 167 & T. physodes M. Bieb. & AZ4336 & 1 & 1 & 1 & 1 & 1 & & W & Mix 6 \\
\hline 168 & T.physodes M. Bieb. & 124667 & & & 1 & 1 & & & W & Mix 6 \\
\hline 169 & T. physodes M. Bieb. & 124669 & & & 1 & 1 & & & W & Mix 6 \\
\hline 170 & T. pratense $\mathrm{L}$. & Tas 1732 & 1 & 1 & & & & & W & Mix 6 \\
\hline 171 & T.tumens M. Bieb. & AZ3048 & & & 1 & 1 & & & W & Mix 6 \\
\hline 172 & T.tumens M. Bieb. & SA 16758 & 1 & 1 & 1 & 1 & 1 & & W & Mix 6 \\
\hline 173 & T.tumens M. Bieb. & Tas 2568 & 1 & 1 & & & & & W & Mix 6 \\
\hline \multirow[t]{2}{*}{174} & Vicia cracca $\mathrm{L}$. & SA38058 & 1 & 1 & & & 1 & & W & SU303 \\
\hline & Total number of entries & 174 & 102 & 102 & 95 & 95 & 94 & 53 & & \\
\hline
\end{tabular}

'Non-leguminous species.

Mix 1: NA1001; SRDI229; SRDI267; WSM1333; WSM1344; WSM1816; and WSM2193.

Mix 4: M49; RRI128; SRDI291; and WSM1115.

Mix 2: SRDI1482; SRDI 1483; SRDI1504; SRDI1507; SRDI1508; and SRDI1520.

Mix 5: CC1099; CC1107; and CC1108.

Mix 6: CC2483; TA1; and WSM409.

Mix 3: CC829; CC856; SRDI110; SU343; and WSM1293.

\section{LITERATURE CITED}

Bell, L.W., M.H. Ryan, M.A. Ewing, G.A. Moore, and P.A. Lane. 2008. Prospects for three Dorycnium species as forage plants in agricultural systems: a review of their agronomic characteristics. Australian Journal of Experimental Agriculture 48:467-479.

Bennett, S.J. (ed.) 2003. Distribution and economic importance of perennial Astragalus, Lotus and Dorycnium. p. 90-115. In New perennial legumes for sustainable agriculture. University of Western Australia, Nedlands, Western Australia, Australia.
Blumenthal, M.J., and T.B. Hilder. 1989. Emergence and early growth of Lotononis bainesii cv. Miles on a cracking clay soil compared with four other tropical legumes. Australian Journal of Experimental Agriculture 29:193-199.

Bureau of Meteorology. 2009. Australian Government, Bureau of Meteorology. Available at http://www.bom.gov.au/weather/ (accessed 2008 to 2010).

Butler, D., B.R. Cullis, A.R. Gilmour, and B.J. Gogel. 2009. ASREML-R, reference manual. Version 3. Queensland Department of Primary Industries and Fisheries, Brisbane, Queensland, Australia. 
Cochran, W.G., and G.M. Cox. 1957. Experimental designs. $2^{\text {nd }}$ ed. John Wiley \& Sons, Oxford, UK.

Cocks, P.S. 2001. Ecology of herbaceous perennial legumes: a review of characteristics that may provide management options for the control of salinity and waterlogging in dryland cropping systems. Australian Journal of Agricultural Research 52:137-151.

Cocks, P.S. 2003. The adaptation of perennial legumes to Mediterranean conditions. p. 35-54. In Bennett, S.J. (ed.) New perennial legumes for sustainable agriculture. University of Western Australia, Nedlands, Western Australia, Australia.

Cullis B.R., A.B. Smith, and N.E. Coombes. 2006. On the design of early generation variety trials with correlated data. Journal of Agricultural, Biological, and Environmental Statistics 11(4):381393.

Dear, B.S., and P.S. Cocks. 1997. Effect of perennial pasture species on surface soil moisture and early growth and survival of subterranean clover (Trifolium subterraneum L.) seedlings. Australian Journal of Agricultural Research 48:683-694.

Dear, B.S., and M.A. Ewing. 2008. The search for new pasture plants to achieve more sustainable production systems in southern Australia. Australian Journal of Experimental Agriculture 48:387396.

Dear, B.S., G.A. Moore, and S.J Hughes. 2003. Adaptation and potential contribution of temperate perennial legumes to the southern Australian wheat belt: A Review. Australian Journal of Experimental Agriculture 43:1-18.

Denton, M.D., C. Sasse, M. Tibbett, and H.R. Ryan. 2006. Root distributions of Australian herbaceous perennial legumes in response to phosphorus placement. Functional Plant Biology 33:1091-1102.

FitzGerald, R.D., E.C. Wolfe, R.H Laby, and D.G. Hall. 1980. Beef production from lucerne and subterranean clover pastures. 2. Bloat occurrence and effect of anti-bloat capsules. Australian Journal of Experimental Agriculture and Animal Husbandry 20:688-694

Gramshaw, D., J.W. Read, W.J. Collins, and E.D. Carter. 1989. Sown pastures and legume persistence: an Australian overview. p. 1-21. In Persistence of forage legumes. American Society of Agronomy, Madison, Wisconsin, USA

Gumbrell, R.C. 1997. Redgut in sheep: A disease with a twist. New Zealand Veterinary Journal 45:217-221.

Gutman, M., A. Perevolotsky, and M. Sternberg. 2000. Grazing effects on a perennial legume, Bituminaria bituminosa (L.) Stirton, in a Mediterranean rangeland. Cahiers Options Méditerranéennes 45:299-303.

Hayes, R.C., G.D. Li, B.S. Dear, A.W. Humphries, and J.R. Tidd. 2009. Persistence, productivity, nutrient composition, and aphid tolerance of Cullen spp. Crop and Pasture Science 60:1184-1192.

Howieson, J.G., J. Malden, R.J. Yates, and G.W. O'Hara. 2000. Techniques for the selection and development of elite inoculant strains of Rhizobium leguminosarum in southern Australia. Symbiosis (Rehovot) 28:33-48.

Hughes, S.J., R. Snowball, K.F.M. Reed, B. Cohen, K. Gajda, A.R. Williams, and S.L. Groeneweg. 2008. The systematic collection and characterisation of herbaceous forage species for recharge and discharge environments in southern Australia. Australian Journal of Experimental Agriculture 48:397-408.

Humphries, A.W., and G.C. Auricht. 2001. Breeding lucerne for Australia's southern dryland cropping environments. (Special issue: Towards a farming future: water control by perennials in cropland). Australian Journal of Agricultural Research 52:153169.

Li, G.D., and P.D. Kemp. 2005. Forage chicory (Cichorium intybus L.) A review of its agronomy and animal production. Advances in Agronomy 88:187-222.

Li, G.D., G.M. Lodge, G.A. Moore, A.D. Craig, B.S. Dear, S.P. Boschma, et al. 2008. Evaluation of perennial pasture legumes and herbs to identify species with high herbage production and persistence in mixed farming zones in southern Australia Australian Journal of Experimental Agriculture 48:449-466.
Li, G.D., Z. Nie, A. Bonython, S.P. Boschma, R.C. Hayes, A.D. Craig, et al. 2010a. Evaluation of chicory cultivars and accessions for forage in south-eastern Australia. Crop and Pasture Science 61:554-565.

Li, G.D., Z. Nie, S.P. Boschma, B.S. Dear, G.M. Lodge, R.C. Hayes, et al. 2010b. Persistence and productivity of a diverse range of Medicago sativa subspecies sativa, caerulea, falcata and varia accessions in 3 intermittently dry environments. Crop \& Pasture Science 61:645-658.

Lolicato, S.J. 1993. Evaluation of perennial pasture legumes for a central Victorian hill environment. In Alternative Pasture Legumes 1993 Technical Report 219. p. 155-158. Primary Industries, South Australia, Australia.

Mendez P., A. Santos, E. Correal, and S. Rios. 2006. Agronomic traits as forage crops of nineteen populations of Bituminaria bituminosa. Grassland Science in Europe 11:300-302.

Muñoz, A., J. Ortiz-Dorda, and E. Correal. 2000. Morphological and molecular characterization of Bituminaria bituminosa accessions from South-East Spain and the Canary Islands. Cahiers Options Méditerranéennes 45:103-107.

Oram, R.N. 1993. The case for increasing biodiversity in the legume component of southern Australian pastures. p. 199-202. In Michalk, D.L., A.D. Craig, W.J. Collins (eds.) Alternative pasture legumes. Technical Report 219. Primary Industries, South Australia, Australia.

Pagnotta, M.A., S. Bennett, P.S. Cocks, M. Ewing, J. Howieson, G. Moore, et al. 2003. Evaluation of perennial legumes collected in Italy, first year data. p. 177-190. Proceeding of the International Workshop Ecology and Survival of Perennial Legumes in Dry Mediterranean Areas, Perugia. 12-14 October 2000.

Pang, J., M. Tibbett, M.D. Denton, H. Lambers, K.H.M. Siddique, M.D.A. Bolland, et al. 2010. Variation in seedling growth of 11 perennial legumes in response to phosphorus supply. Plant and Soil 328:133-143.

Real, D., E. Correal, P. Méndez, A. Santos, S. Ríos Ruiz, M Sternberg, et al. 2009. Bituminaria bituminosa C.H. Stirton (synonym: Psoralea bituminosa L.) FAO Grassland Species. Available at http://www.fao.org/ag/AGP/AGPC/doc/GBASE/ new_species/tedera/bitbit.htm.

Real, D., C.A. Labandera, and J.G. Howieson. 2005. Performance of temperate and subtropical forage legumes when over-seeding native pastures in the basaltic region of Uruguay. (Special issue: Application of rhizobial inoculants to Australian agriculture). Australian Journal of Experimental Agriculture 45:279-287.

Real, D., and A.P. Verbyla. 2010. Maximizing genetic gains using a "plant" model in the Tedera (Bituminaria bituminosa var. albomarginata and var. crassiuscula) breeding program in Australia. Options Méditerranéennes A 92:87-96.

Reed, K.F.M., and P.C. Flinn 1993. Assessment of perennial legumes for acid soils in south western Victoria. p. 152-154. In Michalk, D.L., A.D. Craig, and W.J. Collins (eds.) Alternative Pasture Legumes Technical Report 219. Primary Industries South Australia, Adelaide, South Australia, Australia.

Reed, K.F.M., Z.N. Nie, S. Miller, B.F. Hackney, S.P. Boschma, M.L. Mitchell, et al. 2008. Field evaluation of perennial grasses and herbs in southern Australia. 1. Establishment and herbage production. Australian Journal of Experimental Agriculture 48:409-423.

Robertson, K., L. Bell, R.G. Bennett, D.A. Henry, M. Tibbett, and M.H. Ryan. 2007. Perennial legumes native to Australia - a preliminary investigation of nutritive value and response to cutting. Australian Journal of Experimental Agriculture 47:170176.

Russi, L., S. Bennett, M.A. Pagnotta, H. Norman, B. Nutt, C. Porqueddu, et al. 2003. Ecogeography of perennial legume collecting mission in Italy. p. 161-176. Proceeding of the international workshop "Ecology and survival of perennial legumes in dry Mediterranean areas", Perugia. 12-14 October 2000 . 
Sandral, G.A., B.S. Dear, J.M. Virgona, A.D. Swan, and B.A. Orchard. 2006. Changes in soil water content under annual- and perennial-based pasture systems in the wheatbelt of southern New South Wales. Australian Journal of Agricultural Research 57:321333.

Small, E. 2003. Distribution of perennial Medicago with particular reference to agronomic potential for the semi-arid Mediterranean climate. p. 57-80. In Bennett, S.J. (ed.) New perennial legumes for sustainable agriculture. University of Western Australia, Nedlands, Western Australia, Australia.
Sternberg, M., N. Gishri, and S.J. Mabjeesh. 2006. Effects of grazing on Bituminaria bituminosa (L.) Stirton: a potential forage crop in Mediterranean grasslands. Journal of Agronomy and Crop Science 192:399-407.

Stone, L.M., M. Byrne, and J.G. Virtue. 2008. An environmental weed risk assessment model for Australian forage improvement programs. Australian Journal of Experimental Agriculture 48:568574.

Ventura, M.R., P. Méndez, M.P. Flores, R. Rodríguez, and J.J.R. Castanon. 2000. Energy and protein content of tedera (Bituminaria bituminosa). Cahiers Options Méditerranéennes 45:219-221. 